\title{
Article
}

\section{The Right or Wrong to the City? Understanding Citizen Participation in the Pre- and Post-COVID-19 Eras in Malaysia}

\author{
Seng Boon Lim ${ }^{1,2} \mathbb{D}$, Muhammad Usman Mazhar ${ }^{3}$, Jalaluddin Abdul Malek ${ }^{2}$ and Tan Yigitcanlar ${ }^{4, *(\mathbb{D})}$ \\ 1 Centre of Studies for Town and Regional Planning, Department of Built Environment Studies and Technology \\ (JABT), Universiti Teknologi MARA (Perak), Campus Seri Iskandar, 32610 Bandar Baru Seri Iskandar, Perak \\ Darul Ridzuan, Malaysia; limsengboonn@gmail.com \\ 2 Center for Research in Development, Social and Environment (SEEDS), Faculty of Social Sciences and \\ Humanities, Universiti Kebangsaan Malaysia, 43600 Bangi, Selangor, Malaysia; jbam@ukm.edu.my \\ 3 Department of Management, Nottingham Business School, Nottingham Trent University, 50 Shakespeare St., \\ Nottingham NG1 4FQ, UK; muhammadusman.mazhar@ntu.ac.uk \\ 4 School of Architecture and Built Environment, Queensland University of Technology, 2 George Street, \\ Brisbane, QLD 4000, Australia \\ * Correspondence: tan.yigitcanlar@qut.edu.au
}

Citation: Lim, S.B.; Mazhar, M.U.; Malek, J.A.; Yigitcanlar, T. The Right or Wrong to the City? Understanding Citizen Participation in the Pre- and Post-COVID-19 Eras in Malaysia. J. Open Innov. Technol. Mark. Complex. 2021, 7, 238. https://doi.org/ 10.3390/joitmc7040238

Received: 9 August 2021

Accepted: 24 November 2021

Published: 3 December 2021

Publisher's Note: MDPI stays neutral with regard to jurisdictional claims in published maps and institutional affiliations.

Copyright: (c) 2021 by the authors. Licensee MDPI, Basel, Switzerland. This article is an open access article distributed under the terms and conditions of the Creative Commons Attribution (CC BY) license (https:/ / creativecommons.org/licenses/by/ $4.0 /)$.

\begin{abstract}
The right to the city concept is widely debated in academic discourse yet ambiguously executed in public discourse. In much of the discussion, the right to the city is advocated as a right that humans should claim-i.e., participating in urban space living. Nonetheless, constraints and limits are imposed on such advocacy, resulting in a tokenized implementation state. With such a background surmounting the COVID-19 pandemic era, this study is aimed at understanding the right to the city propagation and revealing the possible wrongs of such civic advocacy. Multiple cases in Malaysia were selected for analysis and as the discussion context representing the state-of-the-art aspect of right to the city in the context of an emerging country. Two potential misconceptions through the action of right to the city were identified: first, the concept of right to the city has the potential to infringe the centrality of power, which both citizens and the authority have to make clear; second, the lack of a sign of contribution from citizens poses a severe challenge to build a co-created urban space for all. This paper contributes to removing a blind spot-the possible wrong to the right to the city-and provides ideas to achieve authentic citizen participation.
\end{abstract}

Keywords: right to the city; wrong to the city; citizen participation; participatory governance; co-created urban space; urban policy; public policy; social advocacy; Malaysia; COVID-19

\section{Introduction}

The 'right to the city' concept represents an influential aspect of today's inclusive city development and human rights claims. Nevertheless, the background to the context lies in the 1960s and 1970s Paris contestation facing Henri Lefebvre, the scholar who coined this unique term [1,2]. The late 1960s were the era of France's technocratic central government, which built large public housing complexes on the outskirts of Paris in the post-Fordist period. They then expelled the working class and immigrants to this new edge [3]. Lefebvre devoted himself to precarious living and urban marginalization in the city space analysis, criticism of the state and the capitalist production model, mainly through Marxist methods and concepts. More recently, the right to the city concept has been reclaimed by social movements as a call to action to reclaim the city as the production of a co-created space [4,5].

For example, the Right to the City Alliance (RTTC) in the U.S. is one of the leading social movements that formed in 2007 in response to the mass displacement of people because of gentrification [6]. The RTTC emerged when several groups-the Miami Workers Center, Strategic Actions for a Just Economy, and Tenants and Workers United-convened a meeting in Los Angeles with 20 community organizations from seven cities to start 
the alliance. The RTTC aims to reframe the central scale of the social struggle from the global to the urban, thus re-centering and advancing the struggle for democratic urban governance [7]. Through advocating that local people should gain the rights to remain in their settlements, preserving local cultures and co-creating city spaces, the RTTC has criticized the authorities for ignoring non-profit parties in the privatization of urban housing space.

The current movement, "Congress: Hold the Line on Housing", propagated by the RTTC and another 40 grassroots organizations from across the U.S., aims to appeal to the Biden government to not make cuts housing investments as part of its Build Back Better agenda. Data co-produced by the National Equity Atlas and the RTTC indicated that the majority of the approximately 5.8 million people who have temporary possession of housing in the U.S. are low-income earners and people of color. Without federal or state protection, they are on the brink of being evicted, having been severely affected by the COVID-19 pandemic [8,9]. However, the Democrats' $\$ 1.85$ trillion Build Back Better agenda, announced in 28 October 2021, has many other issues on which to focus, such as investing in climate change mitigation ( $\$ 550$ billion), extending health care coverage ( $\$ 130$ billion), investing in affordable housing ( $\$ 150$ billion), and creating millions of higherpaying jobs [10,11]. The RTTC is worried by the possible reduction in the allocation for public housing investment from $\$ 150$ billion to $\$ 80$ billion. The RTTC's main concern is advocacy for the resolution of the housing needs and issues experienced by low-income earners and people of color. To the limited knowledge of the authors, there is a lack of evidence that the RTTC is co-creating projects with the authorities. It has been indicated that their voice is focused less on community asset building and more on appealing to community needs for housing as a human right.

In the global south, the movement of Abahlali baseMjondolo, which began in Durban, South Africa in early 2005, is one of the most vocal groups. This is reflected in its focus on gaining the right to the city, as demonstrated in its urban struggles for shack dwellers [12,13]. Abahlali baseMjondolo has won some court cases, for instance, defeating the Slums Act in the Constitutional Court. However, the group also realizes that the militant slogan of 'the right to the city' can be utilized or transformed into the legalistic issue of 'human rights', which is contested in law courts between lawyers [14] but leaves the poor people suffering on the ground. They demand a moral right, the authorities' protection, and the provision of services while objecting to forced evictions or land invasions. To this day, the group is supporting the shack dwellers' struggle, and it seems that not all developments in this struggle have been in the right direction for trying to resolve the shack town problems once and for all.

To achieve the right to the city for the vulnerable, the broader conceptualization has involved rethinking public participation from below $[12,13,15]$. Despite this, challenges are mounting. First, the understanding of the concept of right is ambiguous, as the type of right referred to in the right to the city could be a legal or moral right, or a socioeconomic or political citizenship right. Secondly, it is not fully clear who the urban space stakeholders are that deserve to claim their right. Thus, the question remains regarding for whom this is a right: the working class; the poor and vulnerable; or the upper class and elites. Third, public participation is a buzzword that is easily tokenized by power holders; that is, it is debatable whether this means actually participating in decision making and being consulted, or whether being the beneficiaries of official programs can be considered an act of public participation. Participation from below, or community organizing, has faced numerous issues such as: the lack of organizational ability of civil societies; an excessive focus on demands while lacking self-asset assessment; a lack of funding for mobile projects and paying expenses such as staffing and 'non-expert' citizen overheads; and the complexity of building a consortium of multiple stakeholders when applying for grants. Even after securing funding, there are often constraints on meeting pre-determined milestones and limited citizen scope to reframe the initiatives $[4,6,16,17]$. 
Thus, given the above-mentioned challenges, in this essay the authors intend to investigate possible misconceptions of the right to the city in the context of civic advocacy/citizen participation. The study aims to inquire how citizen participation could be improved by understanding the possible misconceptions of the propagation of rights to the city. Since the issue is complex, it is appropriate to utilize a multiple case study method for gathering and comparing pre- and post-COVID-19 cases of civic participation in Malaysia. The cases selected for analysis in this essay are not limited to social movements but represent a broader picture of political citizenship participation activities in the Malaysian context.

The following section reviews the literature on the exact nature of the right to the city, who has a right to the city, and how to balance this right among city stakeholders. Next, the authors explain the study method and provide the empirical findings on scenarios of participation in cases in the Malaysian context. Disrupted by the current worldwide pandemic COVID-19, the discussion will dissect the pre and post-COVID-19 eras to understand how measures are taken to control COVID-19 have undermined the limited space is available to active citizen involvement in Malaysia. Connected to this, a discussion on the possible wrong to the city intends to provide new insights into creating authentic participation in the post-COVID-19 era.

\section{Literature Review}

\subsection{The Concept of Right}

'The right to the city' has been debated in terms of what type of right this refers to. Lefebvre's definition of the right to the city was that it was a 'transformed and renewed right to urban life' [1]. As a concept, this came under criticism from [18], who argued that it was at best indeterminate, since Lefebvre failed to devote much attention to expanding on the practicalities of this right to the city; that is, Lefebvre's explanation of the right to the city was ambiguous. For him, it was a collectivized concept involving of more old-fashioned rights, such as the right to freedom and individual expression though urban socialization. In fact, the concept of right encompasses far more than the geographical perspective and can be understood through fundamental legal, political, and ethical philosophies (Figure 1).

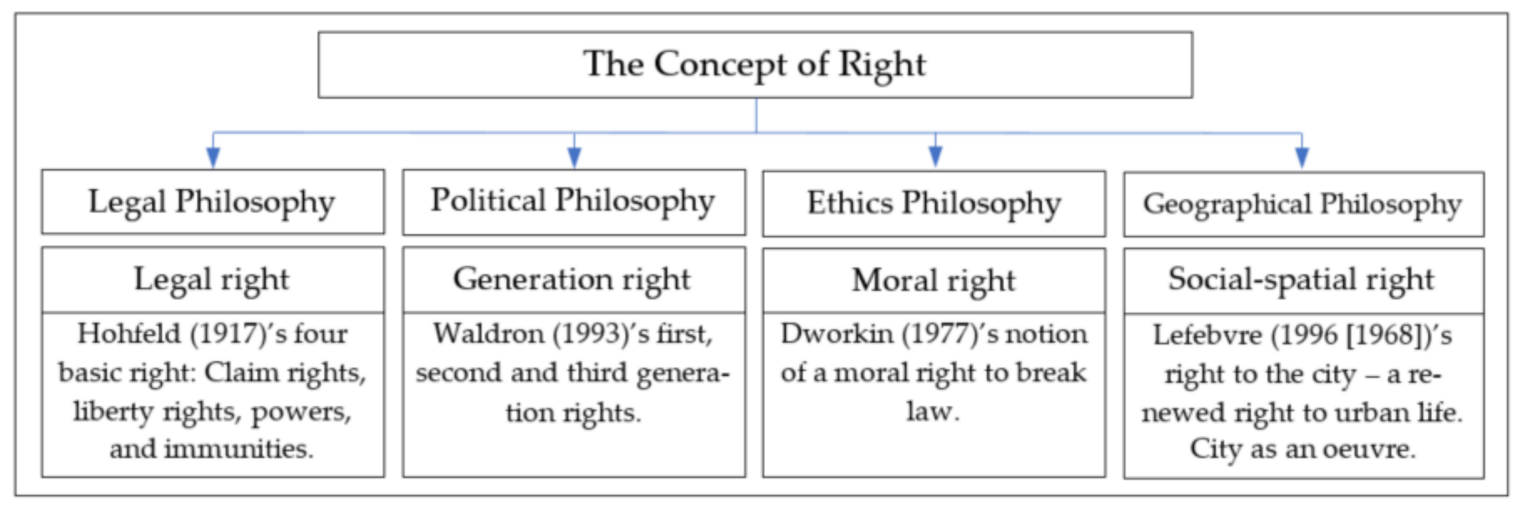

Figure 1. The concept of right.

In legislative terms, ref. [19]'s classical definition of basic (legal rights and their internal infrastructure) rights is worth noting, namely claim rights, liberty rights, powers and immunities. Claim rights are those which are correlated with duty or responsibility. Having a claim right means being subject to a duty. In contrast, liberty rights delineate precisely what the right-holder does not take responsibility for. Having a liberty right means being free of duties. Having power and immunity, according to Hohfeld, can be regarded as holding secondary rights. Having power and immunity allows an individual and a group to change, overturn or neglect current entitlements in law. Having power means having the capability to alter a relationship in law; immunity means being freed from the legal power of another. Thus, the term 'legal rights' has multifaceted meanings and has generally been demonstrated in a mixed context. This may involve, for example, participating in 
municipal programs or meetings, whereby citizens have their claim rights (their duty to protect/improve the community), liberty rights (their free choice to participate as they do so voluntarily), powers (to participate directly or through delegation) and immunities (they are not pressurized or punished by authorities for not participating). As an addition to the claim rights, with which duties are closely linked, ref. $[17,20]$ suggested that civic advocacy should look from within and focus on building community assets (i.e., the skills of local residents) rather than demanding the authority to solve the community's needs (i.e., pollution, domestic violence and unemployment).

In political philosophy, ref. [21] differentiated rights according to first-, second-, and third-generation rights. The concept of first-generation rights is those encapsulated in the Declaration of the Rights of Man of 1789 and the Bill of Rights from the early United States. First-generation rights, as stated by Waldron, mean the traditional freedoms and advantages due to a citizen: freedom of speech; liberty in religion; the right to be spared torture; the rights to equal justice; voting rights; and many more. Meanwhile, second-generation rights can be identified most evidently in the adoption of the Universal Declaration of Human Rights by the UN in 1948. Franklin D Roosevelt invoked second-generation rights when he called for another Bill of Rights. Second-generation rights principally relate to socio-economic rights. These entitlements range from housing rights to the right to fair wages [7]. They are connected to the expansion of the welfare state. As a proponent of second-generation or socio-economic rights, Waldron argued that without a stable socio-economic status, which involves a healthy life, safe shelter and a stable income, the first-generation rights of citizenship could hardly exist and be demanded by societies. Solidarity rights or group rights are terms commonly associated with third-generation rights. Waldron conceived the uniqueness of third-generation rights, since they refer to the safe-guarding of communal property. These rights encompass the language rights of minorities and national self-determination rights, as well as the rights to diverse or abstract possessions like peace, a clean environment, cultural or ethnic integrity and robust economic growth.

Within ethical philosophy, ref. [22] focuses on the complex relationship between moral rights and constitutional law. For Dworkin, rights are best understood as trumps against democratic tyranny. In a democracy, rights represent, as Dworkin states, 'the majority's promise to minorities that their dignity and equality will be respected' even in cases where it is not politically or socially expedient. In other words, in the view of Dworkin the idea of entitlements principally means the concept of negative and individualized rights. The authors view Dworkin's moral rights as thought-provoking. Firstly, are all the moral rights of the citizens recognized in the constitution? Secondly, is it a citizen's duty to follow the law even when it contravenes their moral rights? Alternatively, and more pointedly, is it possible to gain the moral right to infringe the law? Dworkin supported the upholding of moral rights rather than legal rights; that is, the minorities or the vulnerable must be the inclusive concern of the power holders. Hence, given Dworkin's views, and with regard to the right to the city, it may be possible to question whether the right to the city means the right to infringe the law. Taking the example of Abahlali baseMjondolo, this South African shack dweller movement has rightly pointed out that their interpretation of the right to the city is actually their desire for a long-term moral right and the authorities' support of the vulnerable, not simply to contest the authorities' position in case-based law courts using lawyers $[12,14]$.

From a geographical perspective, the right to the city, as explained by Lefebvre, was linked to the (urban space) social justice of the everyday life of the population in a capitalist framing. Lefebvre defined the city as an oeuvre, a piece of art crafted by the lives of everyday people, and a projection of society over the territory, which was open to interpretation based on the socio-spatial element of rights [2]. Lefebvre's initial idea was grounded in the liberal conception of humanism, since he called for an 'effort to reach out towards a new humanism, a new praxis, another man, that of urban society' [1]. He used language such as 'of [the] subject, creative labor and art' to describe the working class 
while for him, the city was humanistic in nature. Thus, recent scholars' interpretations have linked this geographical-humanistic aspect to the rights to urban policy, public space and social justice/exclusion. For instance, ref. [23] referred to the right to autonomous action when facing state urban policy, whereas [24] mentioned the need for the right to counter the brutality of policy, surveillance and state overreach.

\subsection{Who Has the Right to the City, and How to Balance That Right}

Who has a right to the city? Originally, for Lefebvre, the right to the city constituted not a singular right (as explained in the previous section), but a set of rights available to the labor force in terms of how they lived in and produced the space that existed in everyday life in the capitalist world.

In Lefebvre's conception, citizens, particularly the vulnerable and minorities, have the right to demand that the authorities or power holders provide fair and inclusive city living spaces. This urban civic advocacy can be identified in various examples, such as campaigns for the homeless and for water rights in Toronto [23], and those related to immigrants and employment rights in France [25]. As [26] claimed, demanding the right to the city means demanding that the city's resources must be democratically managed. The authors tend to believe that conflict also lies in the distinction between democracy and right. In democracy, it is through utilitarian thinking that the majority benefits and wins at the expense of the minority $[27,28]$; thus, how then should minorities be able to claim their rights under a democratic conception that is protected by legal rights? That is why $[18,24,28]$ commented that the right to the city could be regarded as a radical or negative force against democratic management, collective power or legal power. Furthermore, what people demand from the authorities is a moral right, protection and awareness.

In reality, societies are complex, consisting of not only the vulnerable but also multistakeholders and social groups. The authors of [29] effectively categorized seventeen social groups that held different priorities on values concerning the economy, environment and society in urban settings. For example, the group of urban poor women desire gender equality, which would enable them to participate and benefit equally in society, improve maternal health and have access to reproductive health. Indigenous people expect society to respect their living ecosystem, culture and language, as well as their accuracy in relating histories that claim they, not the latecomers, are indeed the original landowners. Conversely, such demands for social value have conflicted with rich and elite groups who hold the power, the right to exploit land and workers, and the overall prosperity that leads to pride in their city. In the authors' opinion, all groups of people have their own particular right to the city and this concept should be more inclusive. Thus, it is imperative to ask how to balance such rights.

Lefebvre cautioned that such human rights should not be excluded from the centrality, and to participate politically in decision-making is particularly significant for the working class [1]. According to Lefebvre, the centrality of the cause does not imply the center of power but the regrouping of differences concerning each other [1]. This is the centrality of making meaning for the broader urban whole [30]. Thus, for genuine citizen participation in urban governance, the authors support the concept of considering not only the working class but all social groups; indeed, it is particularly necessary to reconcile the differences between social groups [31].

Acknowledging differences among social groups, i.e., the idea of accepting the dissensus that exists among all social groups, is of the utmost importance [32]. Furthermore, all dissensus should build upon the common ground of trade-offs (or 'give and take') where public values should take precedence over personal values. Those supporting the notion of the right to the city need also to recognize that when the 'world [is] characterized by scarcity and conflict,' real trade-offs are created by the institutionalization of any rights [21]. This gathering of opinion dissensus, or trade-offs, resembles the famous term "invitation to struggle," coined by [33]. Similarly, acknowledging that the opinions of all stakeholders 
are unique and diverse, Corwin reasoned that there is a need for power holders to invite or encourage all parties to discuss, deliberate and devise inclusive solutions and outputs [34].

To achieve the authentic state of accepting dissensus in citizen participation, two conditions stated by [35] need to be taken into consideration, namely the involvement of people in the planning stage of the value chain of public services, and the citizen power state in Arnstein's [36] ladder of participation (see Figure 2).

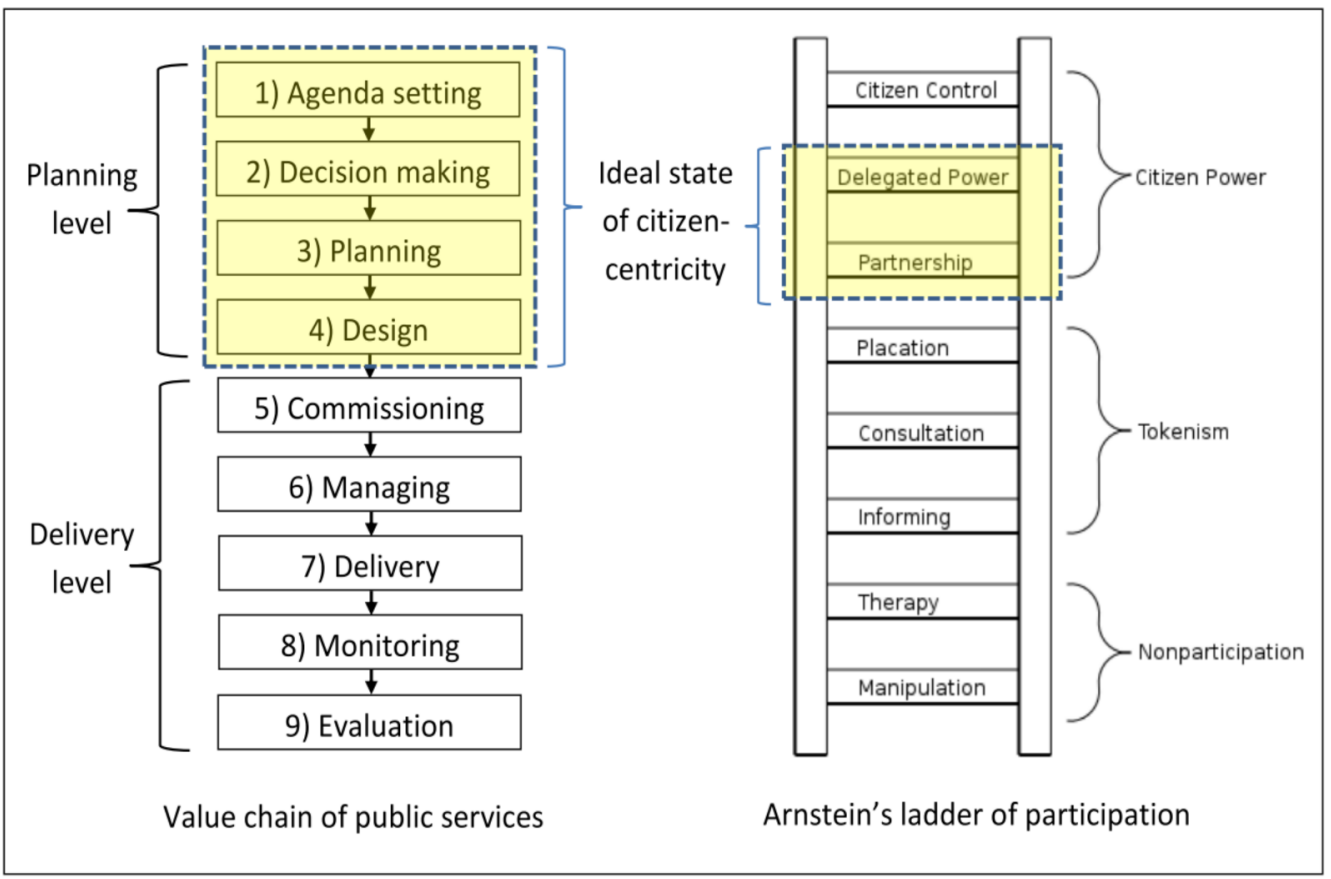

Figure 2. Authentic state of citizen participation, derived from [35].

Based on Figure 2, the right to centralize participation is to bring the differences among social groups into the planning level, i.e., the agenda-setting, decision-making, planning and design. This would occur through the agency of citizen power, namely delegated power and partnership, not to be confused with the tokenism strategy of consultation or informing. In understanding, accepting and tolerating such conditions among the authorities and power holders and the citizens, only the adjusted right to the city and centrality to participation will flourish in practice.

\section{Methodology}

This study applied a multiple-case study method. A case study is a research strategy and an empirical inquiry that investigates a particular contemporary phenomenon within its real-life context [37], whereas multiple-case design, or collective case design, refers to "case study research in which several instrumental bounded cases are selected to develop a more in-depth understanding of the phenomena than a single case can provide" [38].

For data collection, a thorough online literature search on the various cases was performed through the Google search engine and the Web of Science portal, covering June 2020 to early April 2021. Diverse stakeholder literature, i.e., government grey literature, media reports, private sector publications, academic literature and other institution publications [39], were located through the related keywords of "right to the city", "citizen participation", "COVID-19", "Malaysia", and similar terms. Statistics about COVID-19 were also collected from [40] to give an overview of the death threat posed by the pandemic.

The strength of the multiple-case study method depends on multiple sources of evidence, where data must congregate in a triangulating fashion. In this sense, some studies, such as that of [4] need more evidence, including interviews from related stakeholders. In this piece, we did not intend to conduct interviews. Interviews had been conducted 
for the first author's previous studies, such as [16,41-44]. The insights derived from these earlier studies and interviews drove the authors to write this paper in order to relate citizen participation to the concept of the right to the city. The first author has sensed possible misconceptions of these activities of citizens as they participate in city authorities' programs. Thus, this paper reflects insights arising from previous studies. Therefore, the authors found that the eleven cases collected through the literature search were sufficient to meet the research objective.

For data analysis, the authors tabulated the eleven multiple Malaysian case scenarios as shown in Table 1. These case scenarios were analyzed by two strands of period, namely for those in the pre-COVID-19 era compared to those in the post-COVID-19 era. Understanding the changes in civic advocacy in the before and after the COVID-19 pandemic will help analyze potential misconceptions or indefinite areas in the concept of the right to the city.

Table 1. The summary of selected Malaysian cases.

\begin{tabular}{|c|c|c|c|}
\hline Period & Issue & Case Description & Context \\
\hline \multirow{9}{*}{ Pre-COVID-19 era } & \multirow{6}{*}{$\begin{array}{l}\text { Environmental democracy and } \\
\text { environmental impact } \\
\text { assessments (EIA) }\end{array}$} & $\begin{array}{l}\text { World Resources Institute conducted an } \\
\text { Environmental Democracy Index (EDI) rating } \\
\text { of } 70 \text { countries, and placed Malaysia (with a } \\
\text { score of } 0.58 \text { ) near the bottom in } 69 \text { th place [ } 45] \text {. }\end{array}$ & Malaysia in an international context \\
\hline & & $\begin{array}{l}\text { In the Democracy Index of } 2020 \text { [46], Malaysia } \\
\text { scored } 7.19 \text { points out of } 10 \text {, placing it in the } \\
\text { "flawed democracy" segment. }\end{array}$ & Malaysia in an international context \\
\hline & & $\begin{array}{l}\text { Nadiah [47] researched the popular } \\
\text { involvement in terms of legislation and found } \\
\text { that Malaysia has a weak citizen-based } \\
\text { involvement in the EIA compared to European } \\
\text { Union countries. }\end{array}$ & $\begin{array}{l}\text { Malaysia compared to the European } \\
\text { Union context }\end{array}$ \\
\hline & & $\begin{array}{c}\text { In the Bakun Hydro-electric Project (BHP), ref. } \\
\text { [48] found that the BHP has subjugated } \\
\text { indigenous people's rights of participation in } \\
\text { the EIA. }\end{array}$ & $\begin{array}{c}\text { Bakun Hydro-electric Project (BHP) in } \\
\text { Sarawak }\end{array}$ \\
\hline & & $\begin{array}{l}\text { In the Kelau Dam in Pahang, ref. [49] found } \\
\text { that indigenous people's participation in } \\
\text { decision-making was limited and low. }\end{array}$ & Kelau Dam in Pahang \\
\hline & & $\begin{array}{c}\text { In the Penang South Reclamation project (PSR), } \\
\text { ref. [50] commented that the local fishermen's } \\
\text { civic voices were ignored by power holders, } \\
\text { despite the many protests and discussions } \\
\text { with politicians. }\end{array}$ & Penang South Reclamation project \\
\hline & \multirow{3}{*}{$\begin{array}{l}\text { Decision-making process in local } \\
\text { government vis-à-vis urban } \\
\text { governance policy and } \\
\text { political participation }\end{array}$} & $\begin{array}{c}\text { Mariana [51] found a low level of participation } \\
\text { among local authorities in the Local Agenda } 21 \\
\text { in Malaysia. In Petaling Jaya's case, the } \\
\text { community's level of participation was also low, } \\
\text { ranging from the non-participation to the } \\
\text { tokenism levels. }\end{array}$ & $\begin{array}{c}\text { National level and the local level of } \\
\text { Petaling Jaya City }\end{array}$ \\
\hline & & $\begin{array}{l}\text { Lim [43] found Petaling Jaya's level of citizen } \\
\text { participation has progressed to medium, } \\
\text { indicating there were signs and cases of } \\
\text { partnerships and consultations. In contrast, the } \\
\text { scenario of citizen participation in Cyberjaya } \\
\text { was very much lower than in Petaling Jaya. }\end{array}$ & Petaling Jaya and Cyberjaya City \\
\hline & & $\begin{array}{l}\text { Manaf, Mohamed and Lawton [52] examined } \\
\text { public involvement in influencing the } \\
\text { decision-making process in the Kedah, Perlis } \\
\text { and Penang local governments. They } \\
\text { concluded that the people intended to get } \\
\text { involved in the public process, and not just } \\
\text { as consumers. }\end{array}$ & $\begin{array}{l}\text { Two in urban areas and four in rural } \\
\text { areas local governments }\end{array}$ \\
\hline \multirow[t]{2}{*}{ Post-COVID-19 era } & \multirow[t]{2}{*}{$\begin{array}{l}\text { Democracy under emergency, } \\
\text { movement control orders, and } \\
\text { social distancing }\end{array}$} & $\begin{array}{l}\text { Under the declarations of emergency (12th } \\
\text { January to 1st August 2021), parliament, state } \\
\text { assemblies and elections were not allowed to } \\
\text { convene unless a decision was made by the } \\
\text { King [53]. Further, under various movement } \\
\text { control orders, most civic participation } \\
\text { activities in cities were restricted. }\end{array}$ & National level \\
\hline & & $\begin{array}{c}\text { A case of physical public hearing carried out in } \\
\text { the Shah Alam City Council. However, the } \\
\text { authority was caught prevaricating on } \\
\text { degazettement of the Bukit Cerakah } \\
\text { forest reserve [54]. }\end{array}$ & Shah Alam City Council \\
\hline
\end{tabular}




\section{Findings \\ 4.1. Participation Cases of Malaysia in the Pre-COVID-19 Era}

In Malaysia, studies on citizen involvement are discussed in the field related to issues of environmental democracy and environmental impact assessments (EIA), and the decision-making process in local government vis-à-vis urban governance policy and political participation [43]. In general, over the last six decades since Malaysia achieved independence in 1957, the level of citizen participation has remained relatively low [51]. Still, this shows the people's intentions to become involved in the formation of public policy and service [52].

World Resources Institute [45] conducted an Environmental Democracy Index (EDI) rating of 70 countries, and placed Malaysia (with a score of 0.58 ) near the bottom at 69th place, among the lowest Southeast Asian countries when compared to Indonesia (score: 1.8), Thailand (score: 1.38) and the Philippines (score: 1.35). This EDI assessment is based on the three pillars of the United Nations Environment Program's Bali Guidelines of sustainability, namely transparency (accessibility to information), public involvement and justice [55]. In particular, in terms of public involvement, assessments made in legislation, such as the Environmental Quality Act 1976, the Town and Country Planning Act 1976 and the Biosafety Act 2007, show that the general level of public involvement in Malaysia is severely limited, and the power to engage the public lies with administrators.

Moving forward to the latest Democracy Index of 2020 published by [46], Malaysia scored 7.19 points out of 10, still placing it in the "flawed democracy" segment. Despite this, the country experienced considerable improvements after its 2006 performance, in which 5.98 points were scored. After that, Malaysia scored 6.36 (2008), 6.19 (2010, 2011), 6.41 (2012), 6.49 (2013, 2014), 6.43 (2015), 6.54 (2016, 2017), 6.88 (2018) and 7.16 (2019). According to the definition by [46], "flawed democracy" means "those countries have free and fair elections and, even if there are problems (such as infringements on media freedom), basic civil liberties are respected. Nevertheless, there are significant weaknesses in other aspects of democracy, including problems in governance, an underdeveloped political culture and low levels of political participation." To explain the "flawed" situation, Malaysia's political stability has deteriorated since Mahathir Mohamad resigned as prime minister in March 2020. Nevertheless, progress in terms of electoral procedures and pluralist ideas have led to political institutions becoming more democratic [46]. Five categories through which the Democracy Index is assessed are electoral procedures and pluralist ideas, government functions, participation in politics, the culture of politics and civil freedom. Although the Economist Intelligence Unit did not mention where Malaysia has improved in terms of the electoral process and pluralism, the results show that, compared to the country's scores in other categories, Malaysia scored the highest in this category with 9.58 points. In comparison to other Southeast Asian countries, Malaysia ranked 39th out of 167 countries surveyed, followed by the Philippines in 55th place (6.56 points), Indonesia in 64th (6.30), Thailand in 73rd (6.04), and Singapore in 74th (6.03).

Aside from democracy indexes, ref. [47] researched the popular involvement in terms of legislation and found that Malaysia has a weak citizen-based involvement in the EIA compared to European Union countries. Furthermore, regarding the same EIA issue, ref. [56,57] criticized public involvement in the EIA in Malaysia as merely notional, due to weaknesses in regulations and the lack of awareness and skills among the people. A need to review the role of the people was identified.

In researching the relationship between the right to participation and the EIA in the case of Malaysia's Bakun Hydro-electric Project (BHP), ref. [48] found that almost 90\% of the respondents were disappointed with their participation in the EIA, while another $80 \%$ detailed that public officials did not follow the procedure and performed the EIA. The findings not only illuminate how the EIA was used to legitimize a project that should ultimately have been stopped, but also evidence how the BHP has subjugated the rights of participation of indigenous people in the EIA. 
A similar result was also obtained in the case of the Kelau Dam in Pahang, Malaysia [49]. Indigenous people's participation in decision-making was a limited and at a low level, and people were not prioritized except those invited for information sharing. In preparing the EIA report, the public, such as residents, NGOs or other stakeholders, should have played an important role in the agenda-setting stages, such as deciding the affected areas, terrain profiling and in the evaluation stages of identifying the impact and examining the final report. However, according to [49], the preliminary report was prepared internally by the State Department of the Environment's officers and other government agencies without a public consultation stage. The unwillingness of executives and politicians to share the way decisions are made has been criticized and has undermined transparency and accountability, which are key pillars of a democratic society.

In a more recent study on the Penang South Reclamation project (PSR) and the construction of the Pan Island Link 1 (PIL1), ref. [50] commented that the civic voices from the local fishermen and similar parties in attempting to stop the project, which would affect their livelihood and environment, were ignored by the power holders, despite the many protests and discussions with politicians. The result indicated that the political behavior of the leadership might have affected this as they attempted to demonstrate their care for, and attention to, the views of disappointed locals. Actually, leaders in politics understand which schemes to use to ameliorate local disaffection at the right time. They also anticipate that the population tends to neglect the long-term effects of environmental damage, prioritizing instead their main concerns of financial compensation [50].

As for the decision-making process in local government vis-à-vis urban governance policy and political participation, ref. [51] studied the issue of community participation and local governance in Malaysia, using Petaling Jaya, a satellite city of Kuala Lumpur developed in the 1960s, as a case study. She found a low level of participation among local authorities in the Local Agenda 21 in Malaysia. In Petaling Jaya's case, the level of participation among the community was also low, ranging from the non-participation to tokenism levels, and not at the partnership level, as it would ideally be. In the case study, it was found that the local authority tried to emphasize a more open and transparent approach to the process of decision-making. But even if they were willing to participate, there was only limited success in ensuring broad participation and trust in the process. According to [51], the principal challenges are the need for accountability of leaders and politicians, the eagerness of the authorities to confront the consequences of the participatory methods (with responsive, transparent, and consensual decisions) and the prerequisite for participation [44] to be an ongoing obligation made by the authorities themselves rather than merely singular exercises.

In similar cases studied by [43], after a decade of improvement, Petaling Jaya's level of citizen participation progressed to medium, indicating there were signs and cases of partnerships and consultations in situations such as the sustainability community awards, recycling and upcycling in $5 R$ programs and participation in municipal budgeting in 2017 and 2018. However, ref. [43] found that it remains problematic to quantify the amount of civic power being collectively delegated. Intimation of civic power condition was elaborated by [58], among which the public was not allowed to vote in the municipality's full council meetings. As a comparison with Petaling Jaya, ref. [43] also studied the Cyberjaya Smart City that has been portrayed as a future role model of city development in Malaysia and the South East Asia region. In the two decades since its inception in the mid-1990s, the scenario of citizen participation in Cyberjaya has been very much lower than in Petaling Jaya, due to two major factors: (a) a lack of local residents and civil society organizations (CSOs) committing to a positive living environment; and (b) a lack of enthusiastic and high-caliber officers and politicians to lead and promote citizen participation.

In addition to Petaling Jaya and Cyberjaya, ref. [52] examined public involvement in influencing the decision-making process in the Kedah, Perlis and Penang local governments. From the 206 responses to a questionnaire, this study examined the popular perceptions of the services of six local governments (two in urban areas and four in rural areas), as well 
as expectations about the participation of the people. It was concluded that the people intended to get involved in the public process, and not just as consumers. The people's perception of the purpose of involvement was understood as a government activity in giving or receiving feedback from the population, but not in developing and empowering local communities. The main reasons why people did not participate in government programs were their lack of time and their friends' lack of involvement. This type of involvement is traditional, i.e., group-based or collective, and less driven by the use of social media. Furthermore, due to a lack of confidence or trust, respondents felt that their involvement would not influence the decisions made by the local government.

\subsection{Participation Cases of Malaysia in the Post-COVID-19 Era}

As of 13 April 2021, the unprecedented pandemic of COVID-19 is haunting the world, having caused 2.96 million deaths, with its fatality rate still increasing [40]. Emerging and developing countries such as Malaysia have not been spared, and COVID-19 has claimed 1333 lives there to date.

In order for the existing COVID-19 situation to be efficiently regulated, the Government of Malaysia has introduced numerous levels of the Movement Control Order (MCO). These range from stages of high risk to stages of low risk: the Movement Control Order; the Recovery MCO; and the Conditional MCO (Table 2). Enhanced MCOs and Targeted Enhanced MCOs have been introduced in smaller areas where COVID-19 case numbers are high; for instance, residential complexes or offices.

Table 2. Phases of movement control orders in Malaysia during the COVID-19 period, derived from [59].

\begin{tabular}{cc}
\hline Phases & Types of Movement Control Order \\
\hline Phase 1-from 18 March 2020 to 3 May 2020 & Movement Control Order 1.0 (MCO 1.0) \\
Phase 2-from 4 May 2020 to 9 June 2020 & Conditional Movement Control Order (CMCO) \\
Phase 3-from 10 June 2020 to 31 December 2020 & Recovery Movement Control Order (RMCO) \\
Phase 4-from 14 December 2020 to 31 December 2020 & CMCO in the areas with high COVID-19 cases \\
Phase 5-from 1 January 2020 to 31 March 2021 & RMCO nationwide \\
Phase 6-from 13 January 2020 to 4 March 2020 & Movement Control Order 2.0 (MCO 2.0), and Declaration of \\
Current Measure until 14 April 2021 & Emergency (12 January 2021 to 1 August 2021) \\
& CMCO in Kuala Lumpur, Selangor, Johor, Penang and Kelantan; \\
and Recovery RMCO in other eight states.
\end{tabular}

Under such critical conditions, the King (Yang di-Pertuan Agong) of Malaysia, advised by Prime Minister Muhyiddin Yassin, proclaimed a state of emergency in accordance with Article 150 of the Federal Constitution, effective from 12 January to 1 August. The intention of this unexpected measure was to counter the ongoing severity of the COVID-19 pandemic, as it authorized the authorities to concentrate on combating the scourge unhindered [53]. Following suit, the Emergency (Essential Powers) Ordinance 2021 was gazetted. According to the declaration of emergency, Parliament, state assemblies and elections are not allowed to meet, unless a decision is made by the King.

Under such conditions, most citizen participation activities in cities were restricted. All were controlled under the prime minister's prerogative and a special independent committee (to advise the King) without being subject to parliamentary debates. If citizens failed to obey the government orders, they could face a prison sentence of a decade, a maximum RM 5 million fine, or both (Emergency (Essential Powers) Ordinance 2021, Section 9 [1]) [60]. Moreover, the government, public officials and those assigned to issue these ordinances were given legal protection against litigation arising from this enforcement. Significantly, the military was also granted additional powers that are normally within the remit of the police, as stated in the Criminal Procedure Code. Nevertheless, some politicians and civil society groups contended that the emergency is needless. The government had a number of measures available, such as the existing powers and those conferred by the current Infectious Disease Prevention and Control Act [53]. In addition, the opposition 
leader Anwar Ibrahim and certain CSOs filed legal court cases to challenge the decision regarding the emergency declaration and parliamentary suspension [61,62].

Under such pressure, on 21 February 2021, the King granted permission for parliament to be convened during the emergency on a date advised by the prime minister [63] However, the Prime Minister and his committee excused many members of parliament (MPs) for being in the high-risk group (i.e., given that $77 \mathrm{MPs}$ were aged between 61 to 69, while another 19 MPs were aged between 70 to 79), and deferred the reopening of parliament until the state of emergency ends on 1 August [64]. Such an explanation based on "science and data" was condemned by opposition MPs, who commented that failing to obey the King on the reopening of Parliament was "lèse-majesté" [65,66].

At the Malaysian local government level, allowing physical citizen participation in government services, activities and projects were halted under various national movement control orders. Imposing social distancing and guarding group gatherings following Standard Operating Procedures (SOPs) to deter the possible spread of COVID-19 among human contacts was prioritized $[59,67]$. The authors spotted one case of a physical public hearing session following strict SOPs, organized by the Shah Alam City Council Selangor, which was carried out on 8 April 2021. During the public hearing, unpleasant feedback from the public regarding the inability of the Selangor authorities to give a good answer on the degazettement of Bukit Cerakah forest reserve was reported [54]. Other than this, under such precarious conditions, cases of diverting such physical participation to online participation have not been reported, as people and government are still facing constraints and are not yet used to a digital type of participation in the new normal of COVID-19.

In comparison to some international cases, this challenge of transforming physical to digital participation was also reported in Zimbabwe [68]. In America, evidence of San Francisco housing debates went online as the Planning Commission met remotely, streamed live on the city government website due to the unprecedented coronavirus pandemic [69]. Brown-Stevens [70] acknowledged that the physical public participation in local government should change forever in the post-COVID-19 era. For instance, public meetings should have to move online, often connecting with a much wider audience than usual. Brown-Stevens added, "These (digital meetings) should not be seen as temporary measures, but instead as a pilot period for how we completely upend public participation-in the future prioritizing ease of connection and participation over tradition is essential" [70].

\section{Discussion: The Right or Wrong to the City?}

With the surge of COVID-19 and its rising worldwide death toll, the right to the city vis-à-vis citizen participation in urban policy is apparently being explicitly pushed aside. It appears that participation is non-essential and could be ignored once public healthcare is threatened [71]. This scenario is particularly apt as it reflects the argument of [21]: that socio-economic rights, such as health and housing, are more important than moral and citizenship rights, such as democratic participation in urban public space.

As described by Joan Hoey, Editor of the Democracy Index, "The coronavirus pandemic of 2020 posed the question of whether the public should, temporarily, surrender democratic freedoms to save lives. Through their actions the majority of people answered in the affirmative. The problem was they were never really invited to consider it. The quality of any democracy can be measured by the questions it puts to the public for decision or guidance. The pandemic confirmed that many rulers have become used to excluding the public from discussion of the pressing issues of the day and showed how elite governance, not popular participation, has become the norm" [46].

This condition, as described by Hoey, is evident in the case of the Emergency Ordinance in Malaysia. The right to the city was under siege by the power of the Emergency Ordinance, the public's lack of valuation for it and even the democratically elected parliamentarians' opinions. The elite governance was trimmed to an almost exclusive special committee under the leadership of the Prime Minister, inclusion in which was not stated clearly under the Ordinance. For the authors, this situation reveals the first possible wrong: 
the conception that the right to the city has had its implicit potential infringed by the centrality of power, and, according to the top-down outlook, the citizens' right to participate has had to be controlled and surrendered. The term "possible wrong" in this paper carries the weight of potential misconception and is an indefinite topic requiring further improvement and clarification. Indeed, as Lefebvre warned, the right to the city conception has to be interpreted with caution and must show the power holder that the primary aim of the right to the city is not that the public should infringe the practice of elite governance. Implicitly, citizens desire moral rights and support from the authorities but this should not lead to such desires being demonstrated explicitly as breaking the law. In the authors' opinion, a moral right should take the same direction as a legal right and not the radical one of breaking the law, as described by [22]. Cases like those of Abahlali baseMjondolo and the RTTC are useful examples of projecting a fight for the vulnerable through the legal channels of protesting, media broadcasting and negotiating with the authorities. A step further would be for citizens to turn their focus to advocating through different social groups [29], and standing together with the government for co-creation rather than showing signs of violating the centrality of the authorities' power.

Many have reported the impact and challenging conditions faced by those underprivileged social groups, where restrictions on economic and earning activities under COVID-19 have resulted in hunger, learning and education losses, and many more health, social and psychological issues [71-74]. Collectively, the city and country are facing a significant challenge to balance the threat of being infected by COVID-19 while sustaining people's livings and earnings [75-77]. Therefore, it has been suggested that citizens should not claim their rights (which could be interpreted as opposing the authorities, in some conditions) without contributing back to (or co-creating) society. Citizens have to be aware that those claim rights are best accompanied by duties under the legal rights concept outlined by [19]. In other words, citizens have to organize themselves and discover potential assets (i.e., the skills of local residents) from within their communities instead of making excessive demands that the authorities solve the communities' needs (i.e., by addressing pollution, domestic violence, and unemployment) $[17,20]$. However, the question remains about how to reach an equilibrium state of such a co-created space among the community and power holders.

Taking from the idea from [78] under varieties of participation in complex governance, the participatory designs of the concept of the democracy cube is adopted and adapted in this essay. The democracy cube concept has accommodated the range of institutional possibilities for public participation. As [78] illustrated, the mechanism of participation vary along three dimensions: who participates (i.e., the scope of participant selection), how participants communicate with one another and make decisions together (i.e., the extent of authority and power) and how discussions are linked with policy or public action (i.e., the mode of communication and decision). First, the spectrum of participation selection methods ranges from more exclusive to more inclusive, i.e., from the state (expert administrators, and elected representatives) to mini-publics (professional stakeholders, lay stakeholders, random selection, open-targeted recruiting and open-self-selection) and to the public (diffuse public sphere). Second, the spectrum of authority and power ranges from holding the least to the most authority, i.e., from personal benefits, communicative influence, advice and consultation, to co-governance in directing authority. Meanwhile, the spectrum of communication and decision mode ranges from the least to the most intense, i.e., from listening as spectators, expressing preferences, developing preferences, aggregating and bargaining, deliberating and negotiating, to deploying technique and expertise (Figure 3a). All the spectra were described clearly with examples by [78] in achieving a form of co-governing partnership, such as the participatory budget reform. 


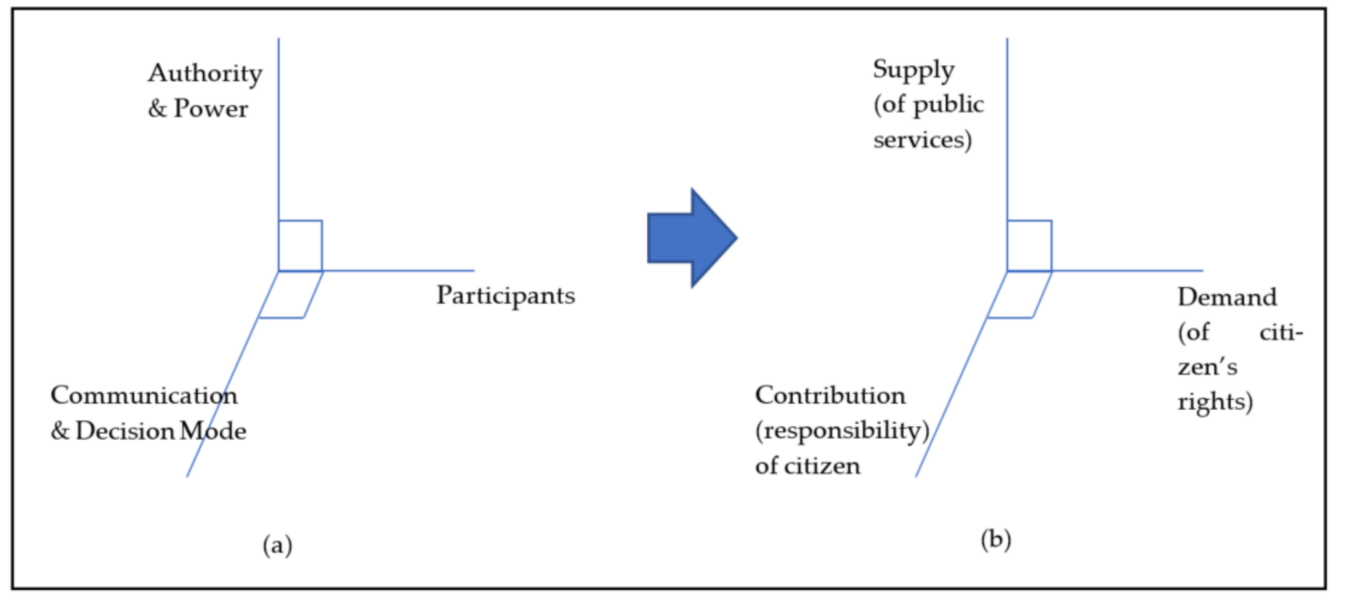

Figure 3. From democracy cube to co-created space. (a) Democracy Cube [78]. (b) Co-created space (authors).

According to [78], this formation of a democratic cube constitutes a space in which any particular mechanism of a public decision can be located to address democratic governance issues. Based on [78]'s idea, the authors found that this concept is suitable for addressing the question of creating equilibrium in a co-created space (Figure 3b). Firstly, the selection methods of participants, ranging from more exclusive to more inclusive, could be applied to the demand for inclusive urban policies or services in a city space that people tend to assume is the only interpretation of citizens' rights $[17,20]$. Secondly, the dimension of authority and power, ranging from least authority to most authority, could be applied to the formation of policies or supply of public services dimension in a city space. The authority formulates policies or supplies public services according to such a spectrum of authorities, and alters them periodically to suit the local context. This leads to the third conception, the communication and decision mode, which has a similar meaning to the contribution, responsibility or assets building of citizens, as citizens have to return effort to the participation process through various modes of communication, as described by [78]. There is an overlapping area, where citizens' contributions or responsibilities also consist of the roles and characters of citizens, which intersects with the concept of participation selection and the communication mode. This has been clarified when referring to the concept of building a citizen-centric city [41] (Figure 4).

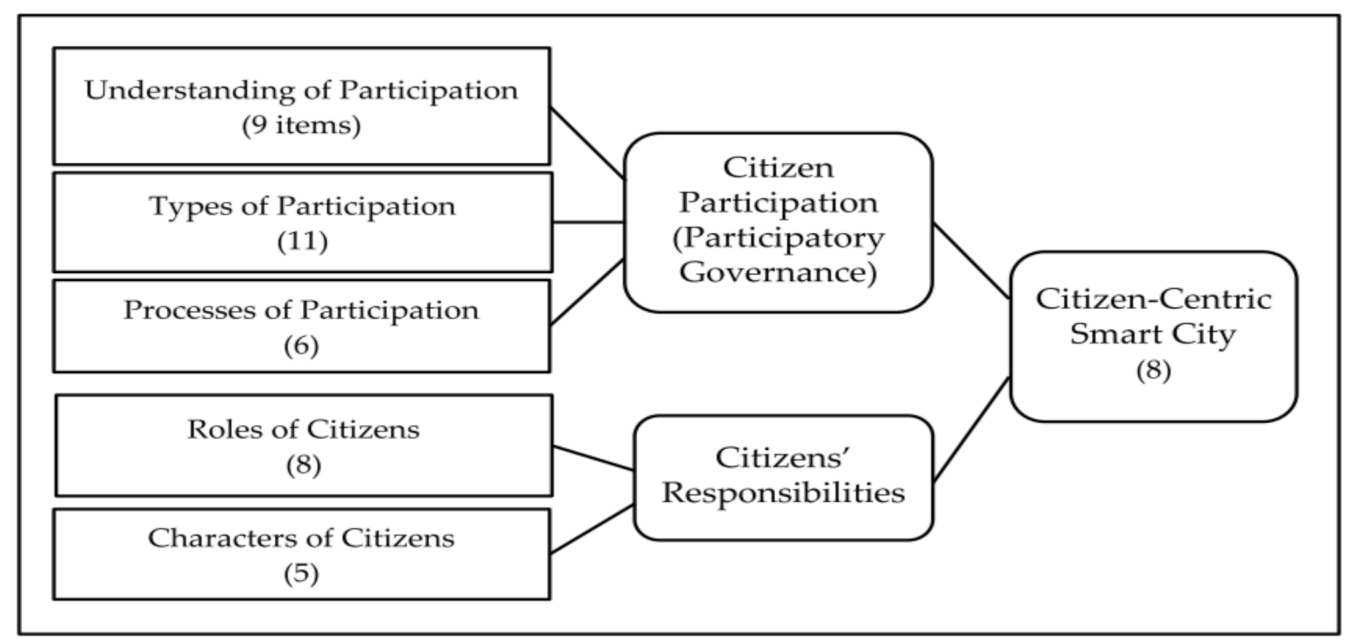

Figure 4. Dimensions in building a citizen-centric city, derived from [41].

This particular point, citizen contribution [41], is, the authors argue, the second possible wrong of the lack of signs of building an equilibrium state in today's co-created city space. People generally tend to forget that duties (or contribution) to claim their 
rights $[18,19]$. They also have the responsibility to contribute back, in collaborating and being conditioned by the participatory design framework. The three dimensions for understanding social citizenship-rights and duties, access and governance, and responsibility mix - were explained by $[79,80]$, and citizens (i.e., family, community, or the market) must play a contributory role in a co-created city space.

This means it is crucial in the future to study various forms of responsibility, i.e., the roles and characters of citizens, and provide evidence to the power holder that they are not intending to infringe the centrality of power but to contribute and advocate for different social groups through individual and cooperative effort with the authorities. Thus, the conception of [41] of the eight roles and five attitudes that are suitable for building a responsible citizen warrants further investigation (Figure 5).

\begin{tabular}{|c|c|c|c|}
\hline No. & Theme & No. & Theme \\
\hline 1 & $\begin{array}{l}\text { Leaders-lead local authorities } \\
\text { to make decisions }\end{array}$ & 1 & $\begin{array}{c}\text { Active involvement is known to } \\
\text { be important }\end{array}$ \\
\hline 2 & $\begin{array}{l}\text { Local champion-takes } \\
\text { the initiative }\end{array}$ & 2 & $\begin{array}{c}\text { Aware and sensitive to what } \\
\text { is happening }\end{array}$ \\
\hline 3 & $\begin{array}{l}\text { Co-producers-work together } \\
\text { Entrepreneurs-bring }\end{array}$ & 3 & Independence in problem-solving \\
\hline 5 & $\begin{array}{l}\text { economic innovation } \\
\text { Solution proposers-advise } \\
\text { and propose }\end{array}$ & 4 & $\begin{array}{l}\text { Higher education allows for } \\
\text { meaningful involvement }\end{array}$ \\
\hline 6 & $\begin{array}{l}\text { Human sensors-supply data, } \\
\text { reports, or complaints }\end{array}$ & 5 & $\begin{array}{l}\text { Interest in public life and } \\
\text { public values }\end{array}$ \\
\hline 7 & $\begin{array}{l}\text { Volunteers-contribute time } \\
\text { and energy }\end{array}$ & & \\
\hline 8 & $\begin{array}{c}\text { Experts - share competencies } \\
\text { or experience }\end{array}$ & & \\
\hline & (a) & & (b) \\
\hline
\end{tabular}

Figure 5. The characteristics of responsible or contributing citizen. (a) The roles [41], (b) The characters [41].

\section{Conclusions}

Claiming the right to the city is no doubt a promising and needed idea that has gained popularity in today's society, whether it takes place in developed, emerging or developing countries. The social movement, i.e., citizen participation, as discussed in this paper, has been coined as a tool to achieve a co-created urban space that fulfils different social groups needs. Nevertheless, this study suspects that there could be a possible wrong (a potential misconception or indefinite area) through the action of right to the city-i.e., the wrong to the city. These are outlined as follows.

First, the right to the city has the potential to infringe the centrality of power, which both citizens and the authority have to make clear. In claiming their moral rights, citizens should cautiously adhere to, not resist, legal rights through the modes of communication and decision, as suggested by [78], i.e., they should take the least or most intense approaches. On the other hand, the authorities should display empathy and realize that the struggle of the people aims to claim a peaceful and inclusive living environment but not, as has been imagined, by infringing the laws and their authoritative power. Furthermore, the authorities are advised to adopt a new perspective by viewing citizens as sources of co-producers and co-creators rather than as burdens or mere beneficiaries of city services [41]. Examples such as the Abahlali baseMjondolo and RTTC cases, as well as the case of engaging citizens in the decision-making processes of the pre- and mid-COVID-19 response in Australia [81-83], could be referred to and used to develop improvements.

Second, the lack of a sign of contribution from citizens poses a serious challenge to building a co-created city space for all. The practice of co-creating city space was in 
evidence before the outbreak of COVID-19 [84-86]. Moreover, the findings of the case studies indicate that the democratic space showed signs of further deterioration under paternalistic elite governance, while an absence of popular participation has become the norm during the pandemic. City co-creation is currently being constrained and restricted under COVID-19 and it would be harmful to the democratic space in the long term if government controls are prolonged. Acknowledging this possibility, this paper strives to identify the differences before and after COVID-19. The authors argue that within such an uncertain area in practice, some ideal conceptions have been mentioned in this paper. For example, the paper has noted that the authentic state of citizen participation, as well as catering for dissensus $[32,33]$ among all social groups, is not limited to the working class or vulnerable, as previously conceptualized by Lefebvre, but lies within the democratic cube, social citizenship and the characteristics of contributing citizens, aiming to provide further clarification.

Although some empirical insights were presented, this study's limitation is that it remains in the conceptual discussion stage. Further empirical investigation is proposed, such as exploring the scope of the characteristics of contributing citizens. Reference could also made to the institutional factors of building community assets $[17,20]$, as well as how balance among stakeholders could be achieved [18] through [21]'s conception of generation rights. Nonetheless, through multiple-case studies, this paper has contributed new ideas about the possible wrong concerning the right to the city, and further crystallized the right to the city concept, particularly from the contributing citizen's perspective.

Lastly, we conclude the paper by highlighting the need for future empirical research on the topic by highlighting the importance of prospective scholarly work with the following quote from [18]: "The question of what kind of right is a right to the city is not, as Jeremy Waldron [21] writes, an attempt to cut the discussion short or police the concept, but rather an attempt to reveal the level of incoherence within the current debate and therefore to sharpen - through critique-the right to the city's political edge. The idea of the right to the city, for all its potential, deserves as much." Particularly in the age of smart cities, the right to the city concept becomes a critical issue to address for our cities [87-90].

Author Contributions: S.B.L. conceptualized the research idea, collected data and wrote the original drafted manuscript. M.U.M., J.A.M. and T.Y. reviewed and edited the manuscript. All authors have read and agreed to the published version of the manuscript.

Funding: The paper received funding support from the Malaysian Ministry of Higher Education (grant number FRGS/1/2019/SS06/UKM/02/2).

Institutional Review Board Statement: Not applicable.

Informed Consent Statement: Informed consent was obtained from all subjects involved in the study.

Data Availability Statement: Data is contained within the article.

Acknowledgments: The authors wish to thank the editor in chief, managing editor and four anonymous reviewers for their invaluable comments and constructive critiques.

Conflicts of Interest: The authors have no financial or proprietary interests in any material discussed in this paper.

\section{References}

1. Lefebvre, H. Writings on Cities; Kofman, E., Lebas, E., Eds.; Blackwell Publishers: Oxford, UK, 1996 [1968].

2. Biagi, F. Henri Lefebvre's urban critical theory: Rethinking the city against capitalism. Int. Crit. Thought 2020, 10, $214-231$. [CrossRef]

3. Galič, M.; Schuilenburg, M. Reclaiming the smart city: Toward a new right to the city. In Handbook of Smart Cities; Augusto, J.C., Ed.; Springer: Cham, Switzerland, 2020; pp. 1419-1436.

4. Cardullo, P.; Kitchin, R. Smart urbanism and smart citizenship: The neoliberal logic of 'citizen-focused' smart cities in Europe. Environ. Plan. C Polit. Space 2019, 37, 813-830. [CrossRef]

5. Purcell, M. Possible worlds: Henri Lefebvre and the right to the city. J. Urban Aff. 2013, 36, 141-154. [CrossRef]

6. Fisher, R.; Defilippis, J. Community organizing in the United States. Community Dev. J. 2015, 50, 363-379. [CrossRef] 
7. Leavitt, J.; Samara, T.; Brady, M. The Right to the City Alliance: Time to democratize urban governance. Progress. Plan. Mag. 2009, 181, 4-12.

8. Right To The City Alliance: Congress: Hold the Line on Housing. Available online: https://righttothecity.org/congress-hold-theline-on-housing/ (accessed on 20 October 2021).

9. Treuhaft, S.; Huang, M.; Ramiller, A.; Scoggins, J.; Langston, A.; Tan, S. Rent Debt in America: Stabilizing Renters Is Key to Equitable Recovery. Available online: https:/ / nationalequityatlas.org/rent-debt-in-america (accessed on 30 October 2021).

10. Adamczyk, A. Here's What's in the Democrats' \$1.75 Trillion Build Back Better Plan. Available online: https://www.cnbc.com/ 2021/10/28/whats-in-the-democrats-1point85-trillion-dollar-build-back-better-plan.html (accessed on 30 October 2021).

11. Levitz, E. The Build Back Better Framework: The Good, the Bad, the Ugly. Available online: https://nymag.com/intelligencer/ 2021/10/the-build-back-better-framework-the-good-the-bad-the-ugly.html (accessed on 30 October 2021).

12. Huchzermeyer, M. Invoking Lefebvre's "right to the city" in South Africa today: A response to Walsh. City 2014, 18, 41-49. [CrossRef]

13. Pithouse, R. Rethinking public participation from below. Crit. Dialogue 2006, 2, 24-30.

14. Abahlali baseMjondolo. The High Cost of the Right to the City. Available online: http://abahlali.org/node/6398/ (accessed on 3 November 2021).

15. Kuymulu, M.B. The vortex of rights: "Right to the city" at a crossroads. Int. J. Urban Reg. Res. 2013, 37, 923-940. [CrossRef]

16. Malek, J.A.; Lim, S.B.; Tahir, Z. Understanding the issues of citizen participation. J. Nusant. Stud. 2019, 4, 1-22. [CrossRef]

17. Mcknight, J.L.; Kretzmann, J.P. Mapping community capacity. In Community Organizing and Community Building for Health; Minkler, M., Ed.; Rutgers University Press: London, UK, 1999; pp. 157-172.

18. Attoh, K.A. What kind of right is the right to the city? Prog. Hum. Geogr. 2011, 35, 669-685. [CrossRef]

19. Hohfeld, W.N. Fundamental Legal Conceptions as Applied in Judicial Reasoning; Yale University: New Haven, CT, USA, 1917. [CrossRef]

20. Block, P.; McKnight, J. The Abundant Community: Awakening the Power of Families and Neighborhoods; Berrett-Koehler Publishers: San Francisco, CA, USA, 2010.

21. Waldron, J. Liberal Rights: Collected Papers 1981-1991; Cambridge University Press: London, UK, 1993.

22. Dworkin, R. Taking Rights Seriously; Harvard University Press: Cambridge, MA, USA, 1977.

23. Phillips, C.; Gilbert, L. Political natures: Re-appropriation of home and water rights in Toronto. In Rights to the City: GU-Home of Geography Publication Series Volume III; Wastl-Walter, D., Staeheli, L., Dowler, L., Eds.; Societa Geografica Italiana: Rome, Italy, 2005; pp. 65-75.

24. Mitchell, D.; Heynen, N. The geography of survival and the right to the city: Speculations on surveillance, legal innovation, and the criminalization of intervention. Urban Geogr. 2009, 30, 611-632. [CrossRef]

25. Dikec, M. Justice and the 'right to the city': The case of French national urban policy. In Rights to the City: GU-Home of Geography Publication Series Volume III; Wastl-Walter, D., Staeheli, L., Dowler, L., Eds.; Societa Geografica Italiana: Rome, Italy, $2005 ;$ pp. 45-55.

26. Harvey, D. The right to the city. New Left Rev. 2008, 53, 23-40.

27. Malek, J.A.; Lim, S.B.; Palutturi, S. The ethics of smart city planning: Examining post-utilitarianism in Malaysian blueprints. In Proceedings of the International Conference on ICT for Smart Society (ICISS 2021), Bandung, Indonesia, 2-4 August 2021; IEEE Conference Publications: Bandung, Indonesia, 2021; pp. 1-5. [CrossRef]

28. Huntington, S.P. Democracy's third wave. J. Democr. 1991, 2, 12-34. [CrossRef]

29. UN-Habitat. World Cities Report 2020: The Value of Sustainable Urbanization; United Nations Human Settlements Programme: Nairobi, Kenya, 2020.

30. Walsh, S. 'We won't move': The suburbs take back the center in urban Johannesburg. City 2013, 17, 400-408. [CrossRef]

31. Lim, S.B.; Malek, J.A.; Yigitcanlar, T. Post-materialist values of smart city societies: International comparison of public values for good enough governance. Future Internet 2021, 13, 201. [CrossRef]

32. Kaika, M. “Don't call me resilient again!”: The New Urban Agenda as immunology ... or ... What happens when communities refuse to be vaccinated with 'smart cities' and indicators. Environ. Urban. 2017, 29, 89-102. [CrossRef]

33. Corwin, E.S. The President: Office and Powers 1787-1857, History and Analysis of Practice and Opinion; New York University Press: New York, NY, USA, 1957. [CrossRef]

34. Foster, D.M. An "invitation to struggle"? The use of force against "legislatively vulnerable" American presidents. Int. Stud. $Q$. 2006, 50, 421-444. [CrossRef]

35. Lim, S.B.; Malek, J.A.; Hussain, M.Y.; Tahir, Z. Citizen participation in building citizen-centric smart cities. Geogr. Malays. J. Soc. 2018, 14, 42-53. [CrossRef]

36. Arnstein, S.R. A ladder of citizen participation. J. Am. Inst. Plan. 1969, 35, 216-224. [CrossRef]

37. Yin, R.K. Case Study Research and Applications: Design and Methods, 6th ed.; Sage: Thousand Oaks, CA, USA, 2018.

38. Mills, A.J.; Durepos, G.; Wiebe, E. Multiple-case designs. In Encyclopedia of Case Study Research; Mills, A.J., Durepos, G., Wiebe, E., Eds.; Sage: Thousand Oaks, CA, USA, 2010; pp. 583-584.

39. Marrone, M.; Hammerle, M. Smart cities: A review and analysis of stakeholders' literature. Bus. Inf. Syst. Eng. 2018, 60, 197-213. [CrossRef]

40. Worldometers. COVID-19 Coronavirus Pandemic. Available online: https://www.worldometers.info/coronavirus / (accessed on 13 April 2021). 
41. Malek, J.A.; Lim, S.B.; Yigitcanlar, T. Social inclusion indicators for building citizen-centric smart cities: A systematic literature review. Sustainability 2021, 13, 376. [CrossRef]

42. Lim, S.B.; Malek, J.A.; Hussain, M.Y.; Tahir, Z. The behaviours and job positions of citizens in smart cities' development. Plan. Malays. 2019, 17, 133-145. [CrossRef]

43. Lim, S.B. Membina Model Bandar Pintar Berpusatkan Rakyat di Malaysia (Constructing Citizen-Centric Smart City Model in Malaysia). Ph.D. Thesis, Universiti Kebangsaan Malaysia, Bangi, Malaysia, 2020.

44. Lim, S.B.; Malek, J.A.; Hussain, M.Y.; Tahir, Z. Participation in e-government services and smart city programs: A case study of Malaysian local authority. Plan. Malays. 2020, 18, 300-312.

45. World Resources Institute (WRI): Environmental Democracy Index: Malaysia. Available online: https: / environmentaldemocracyindex. org/country/mys (accessed on 8 June 2018).

46. Economist Intelligence Unit (EIU). Democracy Index 2020. In Sickness and in Health? Economist Intelligence Unit: London, UK, 2020.

47. Nadiah, M. A Comparatives Study on Public Participation in Environmental Impact Assessment (EIA) in Malaysia and European Union. Master's Thesis, Tilburg University, Tilburg, The Netherlands, 2016.

48. Ho, P.; Nor-Hisham, B.M.S.; Zhao, H. Limits of the environmental impact assessment (EIA) in Malaysia: Dam politics, rent-seeking, and conflict. Sustainability 2020, 12, 467. [CrossRef]

49. Nor-Hisham, B.M.S.; Ho, P. A conditional trinity as "no-go" against non-credible development? Resettlement, customary rights and Malaysia's Kelau Dam. J. Peasant Stud. 2016, 43, 1177-1205. [CrossRef]

50. Lim, S.B.; Malek, J.A.; Hussain, M.Y.; Tahir, Z.; Saman, N.H.M. SDGs, smart urbanisation, and politics: Stakeholder partnerships and environmental cases in Malaysia. J. Sustain. Sci. Manag. 2021, 16, 190-219. [CrossRef]

51. Mariana, M.O. Stakeholder Participation in the Implementation of Local Agenda 21 in Malaysia. Ph.D. Thesis, Universiti Putra Malaysia, Serdang, Malaysia, 2008.

52. Manaf, H.A.; Mohamed, A.M.; Lawton, A. Assessing public participation initiatives in local government decision-making in Malaysia. Int. J. Public Adm. 2016, 39, 812-820. [CrossRef]

53. Hutchinson, F.E.; Zhang, K. Malaysia's Declaration of Emergency Keeps PM Muhyiddin's Window Open. Available online: https:/ / fulcrum.sg/malaysias-declaration-of-emergency-keeps-pm-muhyiddins-window-open/ (accessed on 7 February 2020).

54. Palansamy, Y. Despite Public Hearing, Group Claims Selangor Authorities Prevaricating on Degazettement of Bukit Cerakah Forest Reserve. Available online: https:/ /www.malaymail.com/news/malaysia/2021/04/08/despite-public-hearing-groupclaims\%02selangor-authorities-prevaricating-on-d/1964917?fbclid=IwAR3gYFdZXnmcspbK1ZEXVFP\%02gOLTB0hMVBPO9 3QpHjNufuUOgK4SbCwUuTg (accessed on 7 April 2020).

55. Worker, J.; de Silva, L. Environmental Democracy Index: Technical Note; World Resources Institute: Washington, DC, USA, 2015.

56. Marzuki, A. A review on public participation in Environmental Impact Assessment in Malaysia. Theor. Empir. Res. Urban Manag. 2009, 3, 126-136.

57. Thanarajasingam, S. Law, Policy and the Implementation of the National Conservation Strategy; Prime Minister Department: Kuala Lumpur, Malaysia, 1992.

58. Mohseni, H. Public engagement and smart city definitions: A classifying model for the evaluation of citizen power in 2025 Tehran. GeoJournal 2020, 86, 1261-1274. [CrossRef]

59. Vlaanderen. Corona Virus-The Situation in Malaysia. Available online: https://www.flandersinvestmentandtrade.com/export/ nieuws/corona-virus-situation-malaysia (accessed on 11 April 2021).

60. Malaysia. Ordinan Darurat (Kuasa-Kuasa Perlu) 2021 (Emergency (Essential Powers) Ordinance 2021). Available online: https: / / assets.theedgemarkets.com/pdf/pua_20210114_PUA12-Emergency\%20(Essential\%20Powers)\%20Ordinance\%202021.pdf (accessed on 2 April 2021).

61. Chin, J. Commentary: The Real Question behind Anwar Ibrahim's Legal Challenge over Malaysia Parliament Suspension. Available online: https://www.channelnewsasia.com/news/commentary/anwar-ibrahim-emergency-parliament-suspensionlawsuit-challenge-14052542 (accessed on 7 February 2021).

62. Yatim, H. Seven NGOs including Bersih 2.0 File Suit on State of Emergency. Available online: https: / / www.theedgemarkets. com/article/seven-ngos-including-bersih-20-file-suit-state-emergency (accessed on 7 February 2021).

63. Paramasiwam, M. Parliament Sessions Can Be Carried Out during Emergency-King. Available online: https://www.capitalpost. com.my/2021/02/24/parliament-sessions-can-be-carried-out-during-emergency-king/\#.YHKHSegzacQ (accessed on 11 April 2021).

64. Thestar. Takiyuddin: No Parliament Sitting Until Emergency Ends Aug 1. Available online: https:/ /www.thestar.com.my/news / nation/2021/03/03/takiyuddin-no-parliament-sitting-until-emergency-ends-aug-1 (accessed on 11 April 2021).

65. Palansamy, Y. Failing to Obey Agong on Parliament Reopening Is Lèse-Majesté, Guan Eng Tells Law Minister. Available online: https:/ / malaysia.news.yahoo.com/failing-obey-agong-parliament-reopening-032115628.html?guccounter=1\&guce_referrer= aHR0cHM6Ly93d3cuZ29vZ2xlLmNvbS8\&guce_referrer_sig=AQAAANty3I50zIobCTsiVdvX0Z4i47ted6enAbCS7v34X7sR-fd3 XWVeq85m7pFM7-Cp7NwQ1-zeI0CXTbgcIUujDYc (accessed on 11 April 2021).

66. FTM. No Excuses, Come Clean about Delay in Parliament Sitting, MPs Tell Govt. Available online: https://www. freemalaysiatoday.com/category/nation/2021/03/03/no-excuses-come-clean-about-delay-in-parliament-sitting-mps-tellgovt/ (accessed on 11 April 2021). 
67. Hamdan, M.A. Covid-19: Malaysia Bans Public Gatherings of over 250, to Decide on Apec 2020 Summit. Available online: https: / /www.theedgemarkets.com/article/covid19-malaysia-bans-public-gatherings-over-250-decide-apec-2020-summit (accessed on 11 April 2021).

68. Munyede, P.; Machengete, V.P. Rethinking citizen participation and local governance in the post corona virus pandemic era in Zimbabwe. Transatl. J. Multidiscip. Res. 2020, 2, 1-16.

69. Dineen, J.K. SF Housing Debates Go Online as Planning Commission Meets Remotely. Available online: https: / /www.sfchronicle. com/bayarea/article/SF-housing-debates-go-online-as-Planning-15182948.php\# (accessed on 11 April 2021).

70. Brown-Stevens, A. How Public Participation in Local Government Should Change Forever. Available online: https://www. greenbelt.org/blog/how-public-participation-in-local-government-should-change-forever/ (accessed on 11 April 2021).

71. Yigitcanlar, T.; Kankanamge, N.; Preston, A.; Gill, P.S.; Rezayee, M.; Ostadnia, M.; Xia, B.; Ioppolo, G. How can social media analytics assist authorities in pandemic-related policy decisions? Insights from Australian states and territories. Health Inf. Sci. Syst. 2020, 8, 37. [CrossRef]

72. Tadem, E.C.; Aban, A.P.; Hapal, K.A.F.; Papa, V.B.; Tabiola, H.B.; Sy, J.M.C.; Orlino, M.S.; Dimalanta, R.V.; Candelaria, N.P. A Report on Southeast Asian Community Responses in COVID-19 Time; UP Center for Integrative and Development Studies and Rosa Luxemburg Stiftung: Quezon City, Philippines, 2020.

73. United Nations. Policy Brief: The Impact of Covid-19 on South-East Asia; United Nations: New York, NY, USA, 2020.

74. Hanuschek, E.A.; Woessmann, L. The Economic Impacts of Learning Losses; Organisation for Economic Co-operation and Development (OECD): Paris, France, 2020.

75. Guaralda, M.; Hearn, G.; Foth, M.; Yigitcanlar, T.; Mayere, S.; Law, L. Towards Australian regional turnaround: Insights into sustainably accommodating post-pandemic urban growth in regional towns and cities. Sustainability 2020, 12, 492. [CrossRef]

76. Yigitcanlar, T.; Butler, L.; Windle, E.; Desouza, K.C.; Mehmood, R.; Corchado, J.M. Can building "artificially intelligent cities" safeguard humanity from natural disasters, pandemics, and other catastrophes? An urban scholar's perspective. Sensors 2020, 20, 2988. [CrossRef]

77. Yigitcanlar, T.; Kankanamge, N.; Inkinen, T.; Butler, L.; Preston, A.; Rezayee, M.; Gill, P.; Ostadnia, M.; Ioppolo, G.; Senevirathne, M. Pandemic vulnerability knowledge visualisation for strategic decision-making: A COVID-19 index for government response in Australia. Manag. Decis. 2021. [CrossRef]

78. Fung, A. Varieties of participation in complex governance. Public Adm. Rev. 2006, 66, 66-75. [CrossRef]

79. Jenson, J. Redesigning citizenship regimes after Neoliberalism. Moving towards Social Investment. In What Future for Social Investment? Morel, N., Palier, B., Palme, J., Eds.; Institute for Future Studies: Stockholm, Sweden, 2009; pp. $27-44$.

80. Jenson, J.; Phillips, S.D. Regime shift: New citizenship practices in Canada. Int. J. Can. Stud. 1996, 14, 111-136.

81. Pancholi, S.; Yigitcanlar, T.; Guaralda, M. Public space design of knowledge and innovation spaces: Learnings from Kelvin Grove Urban Village, Brisbane. J. Open Innov. Technol. Mark. Complex. 2015, 1, 13. [CrossRef]

82. Esmaeilpoorarabi, N.; Yigitcanlar, T.; Kamruzzaman, M.; Guaralda, M. How does the public engage with innovation districts? Societal impact assessment of Australian innovation districts. Sustain. Cities Soc. 2020, 52, 101813. [CrossRef]

83. Yigitcanlar, T. Smart city beyond efficiency: Technology-policy-community at play for sustainable urban futures. Hous. Policy Debate 2021, 31, 88-92. [CrossRef]

84. Haustein, E.; Lorson, P.C. Co-creation and co-production in municipal risk governance-A case study of citizen participation in a German city. Public Manag. Rev. 2021, 1-28. [CrossRef]

85. Leading Cities. Co-Creating Cities: Defining Co-Creation as a Means of Citizen Engagement; Northeastern University: Boston, MA, USA, 2013.

86. Leading Cities. Co-Creating Connectivity: Addressing the Citizen Engagement Challenge; Northeastern University: Boston, MA, USA, 2016.

87. Yigitcanlar, T.; Kankanamge, N.; Vella, K. How are smart city concepts and technologies perceived and utilized? A systematic geo-Twitter analysis of smart cities in Australia. J. Urban Technol. 2021, 28, 135-154. [CrossRef]

88. Anastasiu, I. Unpacking the smart city through the lens of the right to the city: A taxonomy as a way forward in participatory city-making. In The Hackable City: Digital Media and Collaborative City-Making in the Network Society; de Lange, M., de Waal, M., Eds.; Springer: Singapore, 2019; pp. 239-260.

89. Van Der Graaf, S. The right to the city in the platform age: Child-friendly city and smart city premises in contention. Information 2020, 11, 285. [CrossRef]

90. Breuer, J.; Walravens, N.; Van der Graaf, S.; Mariën, I. The right to the (smart) city, participation and open data. In Architecture and the Smart City; Figueiredo, S., Krishnamurthy, S., Schröder, T., Eds.; Routledge: London, UK, 2019; pp. $126-138$. 